This item was submitted to Loughborough's Research Repository by the author.

Items in Figshare are protected by copyright, with all rights reserved, unless otherwise indicated.

\title{
Turkey's bid for European Union membership: between "thick" and "thin" conceptions of Europe
}

\section{PLEASE CITE THE PUBLISHED VERSION}

http://dx.doi.org/10.2747/1539-7216.52.2.196

\section{PUBLISHER}

Taylor \& Francis @ Bellwether Publishing, Ltd.

\section{VERSION}

AM (Accepted Manuscript)

\section{PUBLISHER STATEMENT}

This work is made available according to the conditions of the Creative Commons Attribution-NonCommercialNoDerivatives 4.0 International (CC BY-NC-ND 4.0) licence. Full details of this licence are available at: https://creativecommons.org/licenses/by-nc-nd/4.0/

\section{LICENCE}

CC BY-NC-ND 4.0

\section{REPOSITORY RECORD}

Dostal, Petr, Emel Akcali, and Marco Antonsich. 2019. “Turkey's Bid for European Union Membership: Between "thick" and "thin" Conceptions of Europe". figshare. https://hdl.handle.net/2134/16093. 


\section{Turkey's bid for EU membership}

\section{between 'thick' and 'thin' conceptions of EUrope}

\section{Petr Dostál}

Charles University in Prague, Faculty of Science, Department of Social Geography and Regional Development, Albertov 6, 12843 Prague 2, Czech Republic. dostal@ naturr.cuni.cz

\section{Emel Akçalı}

Department of International Relations and European Studies, Central European University, Nador u. 9, 1051 Budapest, Hungary. akcalie@ ceu.hu

\section{Marco Antonsich}

Department of International Relations and European Studies, Central European University, Nador u. 9, 1051 Budapest, Hungary. antonsichm@ ceu.hu

\footnotetext{
Abstract: Turkey's bid for EU membership is one of the most controversial issues that the EU is confronting. Both political elites and public opinions in the EU countries are strongly divided on the possibility of Turkish membership. Since its inception, in October 2005, the negotiation process for Turkey's EU membership has experienced major downturns. Insufficient progress in improvement of human rights, in constitutional adaptations to standard EU constitutional and juridical conditions has been often lamented by the EUropean institutions.
} 
Moreover, the Republic of Cyprus, backed by various other EU countries, has been blocking the negotiation process due to the non-solution of the Cyprus problem. The present article analyzes Eurobarometer survey data on EU enlargement and, specifically, Turkey's EU membership across the twenty-seven polities of the enlarged EU and in Turkey, for the period 2005-2009. The analysis of Eurobarometer survey data points to clear regional differences with regard to Turkey’s EU membership. Moreover, statistical analysis of Eurobarometer data from Fall 2006 indicates two major components around which public perceptions on Turkey's EU membership coalesce. The 'thick' component, built upon the idea that EUrope embodies a specific cultural identity, opposes Turkish membership. The ‘thin' component, made of institutional-procedural norms, leaves instead the door open to Turkey's EU membership. The article argues that it is at the complex intersection of these two opposite views that Turkey's bid for EU membership should be located and eventually decided.

\section{INTRODUCTION}

The question of Turkey's EU membership has sparked long-lasting debates on the cultural identity of EUrope and the cultural, political and economic interests of its state members. ${ }^{1}$ There is not only the issue of self-definition of EUrope founded upon Christianity that is being reconsidered. The dominance of Christian religion at the level of member states and at the level of regional and local communities is also placed in question. The issue has become more salient the more the EU has advanced from a common market towards an ensemble of states integrating their political and cultural affairs. The issue is interwoven with views of Europeanization and affects the EU in a number of respects. For example, the possible accession of Turkey would 
imply changing relations of size, power and socio-economic inequality within an enlarged EU. In the present EUropean confederal-consociational system, in part procedurally based upon population size's differences among member states (Rosamond, 2000; Hix, 2005; Dostál, 2010a, 2010b), Turkey would displace Germany and other large member states as the largest power in terms of number of qualified majority votes in the Council of Ministers and seats in the European Parliament. Lower levels of economic performance of Turkey would also test the socio-economic cohesion regimes of the EU (Molle, 2007; Dostál, 2010c). These general indications show that Turkey's bid for EU membership is one of the most controversial challenges that the EU is confronting today. Among both EUropean political elites and electorates, there have been deepseated concerns about the political, cultural and economic impacts of Turkish membership, even if Turkey were to meet all the Copenhagen political and economic criteria. ${ }^{2}$

The aim of this article is to locate the question of Turkey's EU membership within the views held by public opinions across both the twenty-seven EU state members and Turkey, and, conversely, point to what images of EUrope emerge when this institutional subject confronts the possible membership of Turkey. The article is divided into three sections. In the first one, the authors provide a short overview of the current multi-speed character of EU integration. Before claiming that Turkey would endanger this integration process, the authors argue that it is necessary to consider the existing macro-geography of a differentiated integration of the EUropean space. Within this context, three are the modalities through which Turkey might 'integrate' into EUrope. The second section deals specifically with public opinion survey data over the period 2005-2009 and aims at showing what the major cleavages are in relation to Turkey's EU membership. The third section analyzes a specific data set (Eurobarometer 66.1, 2006), which contains a series of questions related to the conditions which Turkey must satisfy in order to be accepted within the EU. With the help of principal component analysis, two basic 
orientations are specified, which point respectively to a 'thick' idea of EUrope, articulated in cultural-identity terms, and to a 'thin' idea of EUrope, which resonates with legalistic principles (e.g., democracy, human rights and state of law). Finally, in the conclusion the article discusses the limits of this view, by exposing the internal contradictions of the 'thin' principles, which seem unavoidably to confront and to be shaped by 'thick' reasoning.

\section{THE EUROPEAN UNION, MULTI-SPEED INTEGRATION AND THREE TURKISH OPTIONS}

Some scholars commenting on the European integration process have characterized the EU as an 'imperial constellation' (Beck and Grande, 2007; Zielonka, 2006). By looking at the process of European integration, it is possible to identify a differentiated geography which speaks of a multi-speed or asymmetrical political and economic development which today characterizes this spatial constellation. Considering the existing varying intensity of the integration process and looking at the various institutional and procedural mechanisms which regulate the functioning of the EU (Dostál, 2010b), one can identify at least six major zones in the institutional macrogeography and outline three possible modalities of Turkish integration in the EUropean space:

(1) zone of deepest integration: it comprises member states willing to 'pioneer' and form a core group in the EU, such as members of the Eurozone, or those willing to create a common military force;

(2) zone of intensive integration: it includes the twenty-seven member states tied by their efforts to enhance a common market (the so-called first pillar of the EU). This 
embraces the original scope of the European Economic Community, as well as common policy regimes, such as agricultural policy, competition policy, industry, research and development, and environmental and regional policies, over which the EU level retains considerable power and allocates important decision-making competences and financial resources to its governing bodies;

(3) zone of limited integration and cooperation: it includes the twenty-seven member states and deals with both the so-called second pillar (cooperation in common foreign and security policies) and third pillar (cooperation in justice and domestic affairs). This zone is regulated by intergovernmental institutions and is characterized by a series of negotiations among the member states which follow the confederal rules of the EU treaties;

(4) zone of extended power and influence: it includes states which have adopted EU rules and take part in a variety of programs without being formal EU member states (e.g., members of the 1994 European Economic Area (EEA) - Norway, Iceland and Liechtenstein);

(5) zone of candidates countries: it currently includes Croatia, Macedonia, Montenegro, Iceland and Turkey, with their association agreements with the EU;

(6) zone of countries involved in the EU neighborhood policies: this is the socalled EUrope's 'near abroad' and it includes all the countries members of the European Neighbourhood Policy (ENP): Algeria, Armenia, Azerbaijan, Belarus, Egypt, Georgia, Israel, Jordan, Lebanon, Libya, Moldova, Morocco, Occupied Palestinian Territory, Syria, Tunisia and Ukraine. 
This sketch of current multi-speed European integration suggests three modalities of future Turkey's EU 'integration'. The first modality relates to the possible shift of Turkey from the fifth zone of candidate countries to the fourth zone of the institutional macro-geography of EUrope. Such an institutional shift would realize a special relationship of Turkey with the EU. This modality of 'quasi-membership' would avoid the challenge of accepting Turkey’s EU full membership. Discussing the example of Norway, Elliasen and Sitter (2004) put forward the notion of EU 'quasi-membership' and claim that Norway is a test case for indirect participation in European integration processes. The participation of Norway in the EEA is based upon the extension of the Single Market Act by the EEA, but also upon ad hoc Norwegian participation to some other EU initiatives, and adaptations and necessary legal adjustments to EU treaties. The EEA agreement pushes Norway to be involved in the EU common market more than candidate and associated countries and it is upgraded in accordance with each enlargement wave. Norway also secured its participation in the Schengen zone (i.e., the passport free travel area). Since the country has to unilaterally adapt to the EU legal framework and political development, Norway's 'quasi-membership' is obviously asymmetric. The EEA grants participation in the EU internal market (except agriculture and fisheries) and requires acceptance of relevant parts of the EU legal system. However, Elliasen and Sitter also show that the advantages of the 'quasi-membership' tend to shrink with each deepening and widening of the EU. It is essential to note that this general regionalization of European integration processes and the example of Norway reflect the basic asymmetries in the institutional-spatial structure of European political macro-geography. It is clear that there is a need for a set of integrated policies, to which all EU member states must subscribe and which would provide minimal room of maneuver (particularly in the first and second zones), in order to limit the potential centrifugal tendencies in the EU (Dostál, 2010a). Yet, at the same time, the fact that some member states are in this institutional-geographical 
constellation, committed to deepening the integration process, posits an important issue regarding Turkey's possible future integration into this multi-speed EUrope. It is also important to note that the modality of 'quasi membership' resonates too closely with the notion of 'privileged partnership', which has been cherished by the Christian democratic political elite in Germany (Murphy, 2004, 586; Aybet, 2006; Schimmelfenning, 2009), but rejected by the present Turkish government.

The second modality of Turkey's integration in the EU would be a further upgrading of its associated country status, which however would keep Turkey confined with the fifth zone of candidate countries. This modality led to vehement Turkish protests in the recent past (Arıkan, 2003). However, today, thanks to the diplomatic efforts of actual Turkish foreign affairs minister Ahmet Davutoğlu, alternative foreign policy scenarios that put an emphasis on a greater Turkish regional engagement outside EUrope are developing in Turkey. Oft-quoted concepts such as 'Zero problems' and 'maximum cooperation' with Turkey's neighbouring countries are attributed to Davutoğlu's new foreign policy approach which signals a shift from Turkey's unconditional EU quest (Zeynalov, 2010).

The third and last modality would be the high route of full-fledged EU membership within ten or more years. It should be noted that the current Turkish government has decided to choose this modality of full membership, which inevitably generates considerable disciplining and modernizing impacts under the so-called Copenhagen criteria. Acceding countries must also adopt the full acquis communautaire, i.e. the ensemble of rights and obligations that EU countries share. Currently, there are thirty-five chapters under negotiation between the EU and Turkey. The negotiations for Turkey's accession into the EU seem, however, more difficult compared with the recent negotiations of the twelve candidate countries that resulted in the May 2004 and January 2007 enlargements. The reason, as Barkey and Le Gloannec $(2005,131)$ observe, is the 
increasing opposition by EUropean public opinions. In 2005, France introduced an amendment to its constitution, requiring the possibility to organize a referendum on new EU member state if this country represents more than $5 \%$ of the overall EU population - a maneuver clearly aimed at Turkey. Although France decided later on to scrap this amendment, it was followed suit by another country, Austria, which, in August 2008, discussed the possibility to hold a similar referendum in the case of Turkey's successful EU membership. Besides the possibility to put the Turkish question to a public vote, it should also be noted that the negotiation process with the EU would be in any case very uncertain throughout, since the negotiation will have to be accepted by each EU member country, as well as by the European Parliament. Thus, each member state could easily put the negotiation to a halt or at least made them a very difficult and long-lasting affair something which has actually already happened, with the opposition of Greece in particular over the Cyprus question (Akcal1, 2009) All these circumstances would make this modality extremely complicated, due to a variety of political and cultural cleavages in the EU. It is clear that regarding this last third modality, evolving domestic situations and changing public opinions both in EUrope and in Turkey would also be crucial factors to be taken into account.

Debates on Turkey's compatibility and suitability for full membership have always been directed to the question of whether Turkey can be considered a EUropean country. Turkish political elites have traditionally based the 'EUropean character' of their country upon the strong emphasis given to secular and Westernizing measures adopted since the 1923 foundation of modern Turkey by Mustafa Kemal Atatürk and his associates (Mango, 2001; Yavuz, 2009). The problem of identity is, however, an ambiguous one, presenting difficult issues not only for EUrope, which keeps pondering the compatibility of Turkey with EUropean history, values, and identity, but also for Turkey itself. In fact, the legacy of the War of Liberation (1919-1922) has created for present-day Turkey a cultural representation of EUrope as an enemy or a sinister force 
threatening to break up Turkish national unity (Helvaçioğlu, 1999). This representation also has its roots in the so-called 'Sèvres complex'. The Sèvres Treaty - the peace treaty signed between the Ottoman Empire and the Allied Powers at the end of World War I - foresaw the partition of the Ottoman Empire among its ethnic communities, with large territorial shares given to Greek, Armenian and Kurdish populations. Although the War of Liberation (1919-1923), led by Mustafa Kemal Atatürk against the Allied Powers, finally prevented the implementation of the Treaty of Sèvres, this has remained one of the most disturbing reference points in Turkish collective memory (Akçali and Perinçek, 2009). In the Cold War context, however, realpolitik made Turkey side with Western powers. NATO membership happened as early as in 1952 and the demand to become associate membership to the European Economic Community in 1959. This latter geoeconomic move was also influenced by the same demand which Greece made only two months earlier (Dinan, 2005). However, a number of military coups (1960, 1971, and 1980) and the role of the military in the political and juridical system of Turkey strained the relationships with the EEC, later EC and then EU. ${ }^{3}$ Although the collapse of the Soviet-dominated block has significantly altered the character of regional security threats, the geostrategic importance of Turkey does not seem to have diminished. On the contrary, its regional security relevance for the EU has increased in the post-Cold War era (Müftüler-Baç, 2000), which justifies the EU-Turkish rapprochement over the last decade or so. Arıkan $(2003,208)$, for instance, has argued that Turkey's importance for European security is not only related to her role as a stabilizing factor in the regional context, but also to the fact that European security is closely connected with the social, economic and political stability of Turkey itself. Hence, a policy of Turkey's EU accession coupled with a strategy to support political stability in the country would be the most appropriate policy for the mutual security interest of all the parties involved. 
To be true, ever since Turkey became an official candidate during the Helsinki Summit in 1999, a democratization process has gained momentum in the country. EU-driven reforms have positively interacted with domestic developments in Turkey (Tocci, 2005). As the Turkish state elite has come under pressure both from the EU and from the civil society supported by the EU, two major constitutional amendments, and eight legislative packages had been adopted by the Parliament between 2001 and 2004 (Akcal1, 2010). Furthermore, in 2002, the Justice and Development Party (AKP-Adalet and Kalkınma Partisi) has come to power, signaling a marked shift to pro-EU policies. During the AKP term, liberal, left-wing, pro-Kurdish and pro-Islamist civil society forces have found more favorable space and their demands have been increasingly met by political institutions. The AKP, whose founders and majority members have an Islamist background, has also drastically changed Turkey’s traditional foreign policy towards Cyprus, giving its full support to the comprehensive plan of the 2004 UN secretary General for the reunification of the island. Yet, due to the opposition of Greek Cypriots and Greece's negative attitude towards Turkey's EU membership, the Cyprus problem still remains a major road-block on the EU-Turkey negotiations (Akcal1, 2009; Kinaioğlu and Oktay, 2006).

Despite all these reforms, Turkey remains still today rather divided in relation to EU membership and the EUropeanization process. According to Yavuz (2009), two opposite mindsets - 'EUroskeptic' and 'EUrophile' - presently characterize Turkish society, included the proIslamist faction (see also Bilgin and Bilgiç, 2011). "The Euroskeptic position argues that political reforms have made Turkey and Islamic culture vulnerable to European influence, if not manipulation. This position argues that it is important for Turkey to have more political liberties but without 'compromising' its Islamic identity [...]. This defensive mind-set argues that Europe has a double standard when it comes to dealing with Muslim issues; hence reforms in the EU towards increased pluralism are not innocent, there is a hidden agenda" (Yavuz 2009, pp. 212- 
213). The Europhile Islamic mind-set is generally much less skeptical about the EU and domestic measures to fulfill the criteria of the Copenhagen European Council. These criteria are demeed crucial in the democratic and economic transformation of Turkey. Europhile public opinion emphasizes that free access to ideas and civic associations could also benefit the Turkish society. Following the 2002 and 2007 electoral victories of the AKP led by the former Mayor of Istanbul, Recep Tayyip Erdoğan, the political exploitation of the quest for Turkish EU membership has become a key target of AKP governments. Always according to Yavuz (2009, 214), "the large bulk of Turkey's conservative Muslim population continues to support Erdoğan's EU orientation for a number of reasons. They believe that even if Turkey does not become a full member, the EU process offers a framework for addressing civilian-military relations, expanding human rights, promoting economic stability, and realizing the rule of law. In some way, it is the traveling towards EU membership that counts more than the actual arrival at full membership".

\section{PUBLIC OPINION IN THE EUROPEAN UNION AND IN TURKEY}

The May 2004 enlargement to eight post-communist countries in Central and Eastern Europe and to the Mediterranean islands of Cyprus and Malta and the January 2007 enlargement to the Balkan post-communist countries of Bulgaria and Romania were significant in changing the character of the EU in various respects. Symbolically, the two enlargements marked the end of the Cold War division of Europe and seemed to promise a new wave of democratization and economic development (Dinan, 2005). Yet, the national economies of the new member states were relatively poorer and smaller and, as a consequence, the enlarged EU of twenty-seven member states has changed from a compact ensemble of rich countries into a more diverse club. 
This fact should be taken into consideration when analyzing public opinions with regard to further enlargements. According to the most recent Eurobarometer survey (EB 73.4, administered in May 2010), public opinion in the EU-27 is equally divided between those in favor (44\%) and those against (44\%) further enlargement, with a relative minority undecided (12\%) (see Tab. 1).

Tab. 1. Public views on further enlargement of the EU (Values in percent)

\begin{tabular}{|c|c|c|c|c|c|c|c|}
\hline \multicolumn{2}{|c|}{ Public Opinion } & $\begin{array}{c}\text { EB 63.4 } \\
\text { May-June } \\
2005 \\
\text { QA28.4 }\end{array}$ & $\begin{array}{c}\text { EB 65.2 } \\
\text { March-May } \\
2006 \\
\text { QA30.4 } \\
\end{array}$ & $\begin{array}{c}\text { EB 67.2 } \\
\text { April-May } \\
2007 \\
\text { QA27.4 }\end{array}$ & $\begin{array}{c}\text { EB 69.2 } \\
\text { May } \\
2008 \\
\text { QBA37.4 }\end{array}$ & $\begin{array}{c}\text { EB 71.3 } \\
\text { June-July } \\
2009 \\
\text { QA15.2. }\end{array}$ & $\begin{array}{c}\text { EB 73.4 } \\
\text { May } \\
2010 \\
\text { QA20.2 } \\
\end{array}$ \\
\hline \multirow{3}{*}{ EU-15 } & In favor & 46 & 41 & 43 & 44 & 38 & 35 \\
\hline & Against & 42 & 46 & 47 & 45 & 52 & 56 \\
\hline & Don't Know & 12 & 13 & 10 & 11 & 9 & 10 \\
\hline \multirow{3}{*}{ NMS-12 } & In favor & 68 & 60 & 63 & 66 & 58 & 57 \\
\hline & Against & 16 & 22 & 23 & 18 & 28 & 29 \\
\hline & Don't Know & 16 & 18 & 14 & 16 & 15 & 14 \\
\hline \multirow{3}{*}{ EU-27 } & In favor & 55 & 49 & 51 & 53 & 46 & 44 \\
\hline & Against & 31 & 36 & 37 & 34 & 42 & 44 \\
\hline & Don't know & 14 & 15 & 12 & 13 & 12 & 12 \\
\hline \multirow{3}{*}{ Turkey } & In favor & 67 & 45 & 51 & 53 & 47 & 41 \\
\hline & Against & 20 & 29 & 25 & 28 & 37 & 31 \\
\hline & Don't Know & 14 & 27 & 24 & 19 & 16 & 27 \\
\hline
\end{tabular}

However, this equal distribution of public opinion's views at the EU-27 level hides important regional differences. In fact, data in Table 1 shows a clear divide between the old EU member states (EU-15) and the new member states (NMS-12) which joined the EU in 2004 and 2007. ${ }^{5}$ While the former group tends indeed to be against further enlargement, the very opposite is true for the latter group. When analyzed at the country level, Austria (72\% in 2010), Germany (70\%) and France (67\%) are the countries, in the EU-15, whose public opinions are the most 'against' further enlargement. This point is particularly important, since the governments of Germany and France have decisive power, within EUropean politics, in any major decision on future EU development (Dostál, 2010b; Y1lmaz, 2007). In the NMS-12, it is instead the Czech Republic (45\% in 2010), Latvia (39\%) and Slovenia (38\%) to show the largest opposition against further 
EU enlargement. When data are analyzed over time, the general trend, both in the EU-15 and in the NMS-12, points to a constant decline of support for further enlargement, with the only exception of the survey year 2008. Whether the values recorded in this year signal a potential reversal in trend is difficult to say. Most likely, the economic recession which has been felt in EUrope since Fall 2008 has acted as a powerful roadblock over any change in attitude towards further EU enlargement.

As for Turkish respondents, survey values show a rather discontinuous trend, which might be a reaction to the similar discontinuous path of Turkey's EU accession process, as the hope of future membership has periodically been turned down by the opposition of some member states and the difficulties of the negotiation process itself (Akçalı, 2011). Significantly, the lowest support recorded in Turkey is in 2010, which indicates the present disillusionment among Turks about the EUropean future of their country.

When the EU enlargement is analyzed in terms of the specific countries which are to become new member states, survey data shows a divide between Western countries on the one hand and Eastern and Balkan countries on the other hand. Table 2 presents the results for the most recent data set available, EB69.2, administered in March-May 2008. 
Tab. 2 Question "For each of the following countries and territories, would you be in favour or against it becoming part of the European Union in the future?" (source: EB 69.2, QA44, 2008. Values in percent)

\begin{tabular}{|l|c|c|c|c|c|c|}
\hline \multirow{2}{*}{ Country } & \multicolumn{2}{|c|}{ In favor } & \multicolumn{2}{c|}{ Against } & \multicolumn{2}{c|}{ Do not know } \\
\cline { 2 - 7 } & EU-15 & NMS-12 & EU-15 & NMS-12 & EU-15 & NMS-12 \\
\hline Norway & 80 & 83 & 12 & 6 & 9 & 12 \\
\hline Switzerland & 79 & 83 & 12 & 5 & 9 & 11 \\
\hline Iceland & 73 & 77 & 16 & 8 & 11 & 14 \\
\hline Croatia & 50 & 65 & 38 & 20 & 12 & 16 \\
\hline Ukraine & 40 & 60 & 47 & 25 & 13 & 15 \\
\hline Montenegro & 41 & 53 & 44 & 27 & 15 & 19 \\
\hline Bosnia-Herz. & 41 & 51 & 46 & 31 & 13 & 19 \\
\hline Macedonia & 39 & 52 & 46 & 29 & 14 & 19 \\
\hline Serbia & 38 & 49 & 49 & 33 & 13 & 17 \\
\hline Kosovo & 36 & 40 & 51 & 41 & 13 & 19 \\
\hline Albania & 34 & 41 & 53 & 42 & 13 & 18 \\
\hline Turkey & 28 & 38 & 60 & 46 & 12 & 16 \\
\hline
\end{tabular}

The difference between EU-15 and NMS-12 is apparent even in this case. Although both groups rank the potential candidate countries in the same order of preference, respondents in the NMS-12 are always more supportive than respondents in EU-15, as well as more undecided. A clear majority in the EU-15 group support the membership of Norway, Switzerland and Iceland countries clearly belonging to the Western, Christian, affluent world. Croatia is just on the threshold, whereas all the remaining countries are rejected, with Turkey significantly scoring the lowest position.

The negative perception towards Turkey is also confirmed by the short time series over which Eurobarometer surveys asked specifically a question about Turkey's future EU membership (Table 3). 
Tab. 3 Question "Would you be in favor or against Turkey becoming part of the European Union in the future?" (Values in percent)

\begin{tabular}{|c|c|c|c|c|}
\hline \multicolumn{2}{|c|}{ Public Opinions } & $\begin{array}{c}\text { EB 63.4 } \\
\text { 9 May-14 June2005 } \\
\text { QB2.12 }\end{array}$ & $\begin{array}{c}\text { EB 66.1 } \\
\text { 6 Sept-10 Oct 2006 } \\
\text { QA33.13 }\end{array}$ & $\begin{array}{c}\text { EB 69.2 } \\
\text { 25 March-4 May 2008 } \\
\text { QA44.8 }\end{array}$ \\
\hline \multirow{3}{*}{ EU-15 } & In favor & 32 & 27 & 28 \\
\cline { 2 - 5 } & Against & 55 & 61 & 60 \\
\cline { 2 - 5 } & Don't Know & 12 & 12 & 12 \\
\hline \hline \multirow{3}{*}{ NMS-12 } & In favor & 43 & 37 & 38 \\
\cline { 2 - 5 } & Against & 40 & 47 & 46 \\
\cline { 2 - 5 } & Don't Know & 17 & 16 & 16 \\
\hline \hline \multirow{3}{*}{ Turkey } & In favor & 73 & 68 & 61 \\
\cline { 2 - 5 } & Against & 22 & 23 & 25 \\
\cline { 2 - 5 } & Don't Know & 5 & 8 & 13 \\
\hline
\end{tabular}

The divide between the old member countries (EU-15) and the new member states (NMS-12) is once again rather evident. Although in neither of them there is an absolute majority which supports Turkey's EU membership, the NMS-12 group is generally $10 \%$ more in favor than the EU-15 group. The lowest support for Turkey's EU membership was recorded in Austria (8\% over the three survey period), followed by Germany (18\%), Luxembourg (18\%), France (20\%) and Greece (24\%). In the NMS-12, the lowest support was registered in the Republic of Cyprus (17\%), followed by Estonia (28\%), Slovakia (31\%), Czech Republic (33\%) and Latvia (33\%).

In terms of the socio-demographic characteristics of the respondents, the most recent data (EB 69.2) show that the highest percentage of people in favor of Turkey's EU membership are young (15-24 age cohort) and well-educated (holding a university degree) individuals, who share politically leftist views and who live in urban areas. On the opposite, the most numerous respondents against Turkey's EU membership are those aged between 55 and 64 years old, who are not poorly, but moderately educated (i.e., they left school when they were 16 years old), who hold centre-right political views and who live in small/middle towns. Gender is not particularly 
relevant, since male respondents are associated with the highest percent values for both 'in favor' and 'against' answers. This is because there are more women (15\%) than men (10\%) who are undecided on the Turkish issue. Interestingly, the socio-demographic characteristics of those in favor of Turkey's EU membership tend to be the same as those used to statistically explain support for the EU (Gabel, 1988).

When confronted with the possible EU membership of their country, Turkish public opinion expresses high levels of support. ${ }^{6}$ At the individual level, the respondents most supportive of Turkey's EU membership (always on the basis of EB 69.2, 2008) are those in the 45-54 years old cohort, who live in small or middle towns, hold centre-right political views, and have completed high school, although they do not necessarily have a university degree. On the opposite side, respondents of young age (15-24 age cohort), living in large towns, whose political ideas are leftist and who are averagely educated (i.e., they stopped school when they were 18 years old are) are those who show the highest 'against' percent values. This distribution is somewhat surprising, since, for some aspects, it distances itself, on the one hand, from the distribution observed for 'EUropean' respondents and, on the other hand, also from what other studies have shown in relation to Turkish public support for EU membership (Çarkoğlu, 2003). Further statistical analysis, possibly on longitudinal data, is therefore needed in order to shed light on this issue. As for gender, even in the case of Turkish respondents women (20\%) are much more undecided than men $(8 \%)$.

Overall, as Table 3 shows, support for Turkey's EU membership has decreased among Turks since 2005, i.e. the year in which the negotiation with the EU started. This is also true for both EU-15 and NMS-12 respondents. Given the fact that more recent Eurobarometer survey data are not available, it is difficult to hypothesize that the difficult process of Turkey's EU accession has contributed to alienate Turkish public opinion over the years. As a way to investigate further this 
matter, one might look at survey data collected for two other questions, concerning respectively whether EU membership is a good or bad thing and whether it is beneficial or not for Turkey (see Table 4).

Tab. 4 Turkish public opinion on EU membership (Values in percent)

\begin{tabular}{|c|c|c|c|}
\hline \multicolumn{2}{|c|}{ Turkish Public Opinion } & \multirow{2}{*}{$\begin{array}{c}\text { EB 63.4 } \\
\mathbf{2 0 0 5} \\
53 \\
\end{array}$} & \multirow{2}{*}{$\begin{array}{c}\text { EB 72.4 } \\
\mathbf{2 0 0 9} \\
46\end{array}$} \\
\hline \multirow{4}{*}{$\begin{array}{l}\text { EU bad or good? } \\
\text { (QA8b) }\end{array}$} & Good & & \\
\hline & $\mathrm{Bad}$ & 7 & 26 \\
\hline & Neither good nor bad & 30 & 19 \\
\hline & Don't Know & 10 & 9 \\
\hline \multirow{3}{*}{$\begin{array}{l}\text { Would Turkey benefit? } \\
\text { (QA9b) }\end{array}$} & Benefit & 62 & 50 \\
\hline & No benefit & 16 & 34 \\
\hline & Don’t Know & 22 & 15 \\
\hline
\end{tabular}

Questions: "Generally speaking, do you think that Turkey's membership of the European Union is a good thing, a bad thing, neither good nor bad, don't know"; "Taking everything into account, would you say that Turkey would benefit or not from being a member of the European Union?"

The results clearly point to a decline in the positive attitudes of Turks towards the European Union. Respondents, who in 2005 were undecided about whether the EU is good or bad for Turkey, showed clearer negative attitudes in 2009. Similarly, those who in 2005 thought that Turkey could benefit from EU membership had significantly shrunk four years later. This might confirm that, during the period of the negotiation process, the resistances on the EUropean side to Turkey's final membership were clearly resented by Turkish public opinion. However, this trend does not emerge so clearly when another survey series is taken into consideration. Over the last few years, a private Turkish survey firm, Infakto Research Workshop, has administered surveys in Turkey on behalf of the International Republican Institute, a US-based organization, financially supported by the US government, working for the promotion of democracy across the 
world. Among the questions periodically asked to Turks by Infakto, there also is the question related to Turkey's EU membership. Table 5 shows the results for the available survey years. ${ }^{7}$

Tab 5. Turkish public opinion 'for' or 'against' Turkey's EU membership (Values in percent)

\begin{tabular}{|l|c|c|c|c|c|c|c|}
\hline EU membership & Nov-06 & June-07 & Apr-08 & Feb-09 & May-10 & Sept-10 & Dec-10/Jan-11 \\
\hline For & 60 & 58 & 61 & 64 & 61 & 63 & 55 \\
\hline Against & 30 & 30 & 28 & 26 & 28 & 25 & 34 \\
\hline Don't Know & 11 & 12 & 11 & 10 & 11 & 12 & 11 \\
\hline
\end{tabular}

From the above table, it is clear that the support for Turkey's EU membership has not significantly changed since the time the negotiations with the EU started. Only the latest survey, administered between December 2010 and January 2011, shows a noteworthy decline in support against an unvaried percentage of 'Don't know' answers. ${ }^{8}$ On the basis of these surveys it is therefore difficult to affirm that the extenuating EU negotiation process and the negative attitudes in some major EU countries (Germany and France, in particular) have significantly impacted on Turkish public opinion's support for their country's EU membership. Similarly, the recent economic crisis which has severely hit the EUropean economies, but has left almost untouched Turkey, does not seem to have conditioned Turkish public opinion. For sure, the more energetic foreign policy conducted under the leadership of the actual Turkish Prime Minister, Tayyip Erdoğan, aimed at rising Turkey’s profile as an international player, has contributed galvanizing Turkish public opinion (Zeynalov, 2009; Davutoğlu, 2008). Under this new, more assertive foreign policy, Turkey increasingly emerges as an autonomous player, well respected on the international stage and particularly in the Middle East at large. Yet, it does not seem, so far at least, that this new profile has translated into less a demand for EUrope. When asked about the reasons to join the EU, Turks indeed put economic advantages first (49\% in the Dec 2010/ Jan 2011 Infakto survey). From this perspective, the EU is not as much an identity question as 
Turkey is instead for EUrope. Joining the EU is not being perceived as a way to strengthen Turkey's international standing or reinvigorating Turkey's self-esteem. This is why there is a relevant disparity in percentage between those who affirm to be in favor of Turkey to become a EU member state (73\% in 2005) and those who affirm that Turkey's EU membership is a good thing (53\% in the same year). This contradictory opinion seems to point to the idea that Turkey EU membership is perceived by Turkish people as something which can happen in the future, yet they do not necessarily hold a positive image of EUrope and, in any case, EUrope is perceived more in utilitarian terms ( $62 \%$ in 2005$)$ than in terms of a 'good thing' in general. ${ }^{9}$

\section{THICK AND THIN PERCEPTIONS OF TURKEY ACROSS THE ENLARGED EU 27}

In Fall 2005 (EB 64.2) and 2006 (EB 66.1), Turkey's EU membership was the focus of some specific Eurobarometer questions. Respondents were asked to answer whether they 'totally agree', 'tend to agree', 'tend to disagree' or 'totally disagree' in relation to the following nine statements: 1) “Turkey partly belongs to Europe by its geography”; 2) “Turkey partly belongs to Europe by its history"; 3) "Turkey's accession to the EU would strengthen the security in this region"; 4) "Turkey's accession to the EU would favour the mutual comprehension of European and Muslim values" (EB 64.2 only); 5) “The cultural differences between Turkey and the EU Member States are too significant to allow it to join the EU”; 6) "Turkey accession would favour rejuvenating an ageing European population”; 7) “Turkey’s joining could risk favouring immigration to more developed countries in the EU"; 8) "To join the EU in about ten years, Turkey will have to respect systematically Human Rights"; 9) "To join the EU in about ten years, 
Turkey will have to significantly improve the state of its economy". Table 5 shows the results of both surveys. 
Tab. 5 Turkey-EU relations (EB 64.2, 2005; EB 66.1, 2006 - Values in percent)

\begin{tabular}{|c|c|c|c|c|c|c|c|c|c|c|c|c|c|c|c|c|c|c|c|}
\hline & & \multicolumn{2}{|c|}{ geography } & \multicolumn{2}{|c|}{ history } & \multicolumn{2}{|c|}{ security } & \multicolumn{2}{|c|}{ EU-Muslim } & \multicolumn{2}{|c|}{ culture } & \multicolumn{2}{|c|}{ rejuvenation } & \multicolumn{2}{|c|}{ immigration } & \multicolumn{2}{|c|}{ H. rights } & \multicolumn{2}{|c|}{ economy } \\
\hline & & 2005 & 2006 & 2005 & 2006 & 2005 & 2006 & 2005 & 2006 & 2005 & 2006 & 2005 & 2006 & 2005 & 2006 & 2005 & 2006 & 2005 & 2006 \\
\hline \multirow{5}{*}{ EU-15 } & $\begin{array}{c}\text { Totally } \\
\text { agree }\end{array}$ & 19 & 19 & 10 & 10 & 9 & 9 & 9 & - & 28 & 34 & 6 & 7 & 29 & 32 & 67 & 68 & 47 & 49 \\
\hline & $\begin{array}{c}\text { Tend to } \\
\text { agree }\end{array}$ & 35 & 35 & 28 & 27 & 25 & 24 & 28 & - & 29 & 29 & 23 & 22 & 35 & 34 & 19 & 20 & 31 & 30 \\
\hline & $\begin{array}{l}\text { Tend to } \\
\text { disagree }\end{array}$ & 21 & 21 & 28 & 29 & 28 & 29 & 27 & - & 21 & 19 & 29 & 30 & 16 & 16 & 3 & 3 & 7 & 6 \\
\hline & $\begin{array}{c}\text { Totally } \\
\text { disagree }\end{array}$ & 15 & 14 & 20 & 19 & 23 & 23 & 22 & - & 9 & 7 & 21 & 21 & 7 & 6 & 2 & 2 & 3 & 2 \\
\hline & DK & 10 & 11 & 14 & 14 & 15 & 14 & 14 & - & 13 & 11 & 20 & 21 & 13 & 13 & 8 & 8 & 12 & 12 \\
\hline \multirow{5}{*}{ NMS-12 } & $\begin{array}{c}\text { Totally } \\
\text { agree }\end{array}$ & 22 & 21 & 13 & 13 & 10 & 10 & 9 & - & 23 & 26 & 5 & 6 & 31 & 32 & 50 & 50 & 41 & 41 \\
\hline & $\begin{array}{c}\text { Tend to } \\
\text { agree }\end{array}$ & 38 & 39 & 33 & 34 & 27 & 26 & 27 & - & 29 & 32 & 18 & 19 & 33 & 34 & 28 & 30 & 32 & 35 \\
\hline & $\begin{array}{l}\text { Tend to } \\
\text { disagree }\end{array}$ & 16 & 17 & 22 & 23 & 26 & 27 & 26 & - & 21 & 20 & 29 & 28 & 13 & 12 & 4 & 4 & 6 & 5 \\
\hline & $\begin{array}{c}\text { Totally } \\
\text { disagree }\end{array}$ & 9 & 8 & 14 & 13 & 17 & 17 & 18 & - & 7 & 5 & 22 & 22 & 5 & 4 & 3 & 2 & 3 & 2 \\
\hline & DK & 15 & 14 & 18 & 17 & 20 & 20 & 20 & - & 19 & 18 & 26 & 25 & 19 & 18 & 15 & 14 & 19 & 17 \\
\hline \multirow{5}{*}{ Turkey } & $\begin{array}{c}\text { Totally } \\
\text { agree }\end{array}$ & 28 & 30 & 21 & 24 & 32 & 33 & 31 & - & 24 & 29 & 40 & 45 & 30 & 35 & 41 & 45 & 44 & 45 \\
\hline & $\begin{array}{c}\text { Tend to } \\
\text { agree }\end{array}$ & 32 & 32 & 28 & 32 & 30 & 32 & 30 & - & 23 & 26 & 30 & 31 & 27 & 29 & 28 & 29 & 27 & 27 \\
\hline & $\begin{array}{l}\text { Tend to } \\
\text { disagree }\end{array}$ & 11 & 12 & 16 & 15 & 13 & 12 & 14 & - & 20 & 17 & 8 & 7 & 15 & 13 & 8 & 6 & 8 & 9 \\
\hline & $\begin{array}{c}\text { Totally } \\
\text { disagree }\end{array}$ & 15 & 10 & 19 & 12 & 8 & 8 & 8 & - & 15 & 12 & 5 & 3 & 9 & 5 & 6 & 6 & 5 & 5 \\
\hline & DK & 15 & 15 & 16 & 16 & 17 & 15 & 17 & - & 19 & 15 & 17 & 15 & 20 & 19 & 17 & 14 & 17 & 14 \\
\hline
\end{tabular}


Looking at the data for EU-15 and NMS-12, it is interesting to observe that there is no major variation between the two surveys: respondents seem to hold rather stable views when it comes to evaluate Turkey in relation to EUrope. Only the item 'cultural differences' shows a relatively higher increase over time, particularly in the EU-15 group (+6\%), followed by a higher concern for immigration (+3\%) always in the same group. Overall, the trend already observed above, namely the more positive attitude towards Turkey of NMS-12 respondents, clearly emerges also from these two rounds of surveys. Interestingly, as shown by the difference in 'don't know' answers, people in the EU-15 seem to be more opinionated than those in the NMS-12. This seems to point to the fact that Turkey is more central an issue in the former than in the latter group. Looking at all the nine survey items, it is clear that Turkey is generally perceived more of an issue than an asset in relation to its accession to the EU - once again more in the EU-15 than in the NMS-12. According to the respondents of both groups of countries, in fact, it would neither help rejuvenating an old EUropean population, nor furthering security in the region, thus recanting the scholarly opinion on this latter point, as discussed above. On the contrary, it would risk favoring immigration - an issue increasingly and equally feared by both Western and Eastern-Southern EUropeans. A relative majority in both the EU-15 and the NMS-12 is also skeptical about Turkey's EU membership favoring a dialogue between EUropean and Muslim values. If there is only one point which an absolute majority of respondents believe might connect, at least partially, Turkey to EUrope this is geography and, at least for a relative majority in the NMS-12, history as well. This latter view might obviously be influenced by the long history of contacts of the new member countries with the Ottoman Empire and later with Turkey (Mango, 2001). Yet, this geographical and, to a less extent, historical commonality is overshadowed by overwhelming majorities of people who perceive Turkey as a country very far 
away from EUrope when it comes to protection of human rights (the item on which both EU-15 and NMS-12 respondents agreed the most), economic standing and, more marginally, culture. ${ }^{10}$

When the data are analyzed at a country level, there is not one single country which emerges constantly at the top (or at the bottom) of the list for all the nine survey items. However, the tendency in the EU-15 group is for Greece, followed by Austria, Cyprus and Germany (but, interestingly, not France) to show the highest negative attitudes, whereas Spain and, to a less extent, Portugal, Ireland and Northern Ireland show the most favorable attitudes. Within the NMS-12, it is instead the Czech Republic, followed, by Slovakia and Slovenia to show the most recurrent negative attitudes, whereas Romania is by far the most favorable, followed by Bulgaria.

To some respects, Turkish respondents share the same views of EUropeans, although to a less or larger degree according to whether the survey item reveals, respectively, a more negative or more positive character/role of Turkey. Thus, Turkish respondents also believe that Turkey's EU membership would increase the migratory pressure on the most affluent EU countries and that Turkey does have a problem in terms of protection of human rights and economic standing. Yet, they believe so to less an extent than the EUropeans - although in the passage from 2005 to 2006 the figures are on the raise. Similarly, Turkish respondents also believe that geography partially unites Turkey to EUrope, yet to a larger extent than Western EUropean believe so. As for shared history, once again Turks are more convinced in general that this is the case, even though the cumulative percentage of respondents who agree (49\% in 2005 and $56 \%$ in 2006) are not particularly high when compared to other survey items. This is also true for the question about 'cultural differences' between Turkey and EUrope, in regard to which Turkish respondents are more divided than compared to other survey questions. Although Turks perceive neither history, nor culture as obstacles for their integration into EUrope, it is clear that some signs of division within Turkish society emerge on these topics, confirming the tension between EUrophiles and 
EUroskeptics. Even if Turkish respondents acknowledge the issues that concern EUropeans (immigration, human rights, economic disparity), at the same time they largely agree, contrary to the EUropeans, that Turkey's EU membership would definitely benefit EUrope in terms of demography (rejuvenation being the survey item with the highest score), security (thus confirming in this case the scholar perspective discussed above), and also favoring the mutual comprehension of EUropean and Muslim values. In this latter sense, Turks do perceive their country as a sort of bridge between EUrope and the larger Middle East, which is the geopolitical function often discussed in the literature (Yanık, 2011). The percentage of 'don't know' answer is rather similar to the one registered in the NMS-12, yet from 2005 to 2006 Turkish respondents had become more opinionated, increasing the percentage of the cumulative 'agree' answer for all the survey items. This shows an increased awareness of Turks towards the issues that might prevent their country to join EUrope, but also in relation to the assets which Turkey might bring in its EU bid.

It is our argument that the above statements included in the Eurobarometer surveys are not only revealing of what image people have of Turkey, but they can also be telling of the type of EUrope which is envisioned. There is already a rich literature on the cultural character and identity of EUrope (see, just to quote a few, Habermas, 2001; Morgan, 2005; Baykal, 2005; McCornick, 2009). Within this literature, one of the major source of debate is the 'national' or 'post-national' character of EUrope (Antonsich, 2010), i.e. the extent to which EUrope might need a common identity built around shared history and culture or the mere functioning of democratic legal institutions and procedural norms might suffice to give EUrope a demos. This distinction can also be labeled, respectively, as 'thick' and 'thin' EUrope. While a 'thin' EUrope would make possible for Turkey to join the EU as soon as it manages to comply with all the legal 
requirements of the negotiation process, 'thick' EUrope would make this membership much more problematic.

As a way to analyze further this distinction of 'thin' and 'thick' EUrope as it also emerges in public opinion's views, we have decided to run a principle component analysis (Rummel, 1970) on the eight statements concerning Turkey's EU membership asked in the survey EB 66.1 (2006) to respondents of twenty-nine states (EU-15, NMS12, and the two candidate countries, Turkey and Croatia).

Tab. 6 'Thick' and 'thin' perceptions of Europe reflected in public opinion on Turkey principal component analysis (EB 66.1, 2006)

\begin{tabular}{|l|c|c|}
\hline \multicolumn{1}{|c|}{ Survey questions } & $\begin{array}{c}\text { Component } \\
\text { loadings } \\
\text { 'Thick' perception }\end{array}$ & $\begin{array}{c}\text { Component } \\
\text { loadings } \\
\text { 'Thin' perception }\end{array}$ \\
\hline $\begin{array}{l}\text { Net opinion that Turkey does not belongs to Europe by its geography } \\
\text { (QA34.1) }\end{array}$ & 0.811 & -0.429 \\
\hline $\begin{array}{l}\text { Net opinion that Turkey does not belong to Europe by its history } \\
\text { (QA34.2) }\end{array}$ & 0.834 & -0.322 \\
\hline $\begin{array}{l}\text { Net opinion that accession of Turkey would not strengthen regional security } \\
\text { (QA34.3) }\end{array}$ & 0.858 & 0.090 \\
\hline $\begin{array}{l}\text { Net opinion that cultural differences between Turkey and the EU member states are } \\
\text { too significant to allow for its accession (QA34.4) }\end{array}$ & 0.853 & -0.180 \\
\hline $\begin{array}{l}\text { Net opinion that accession of Turkey to the EU would not favour rejuvenation of } \\
\text { population (QA34.5) }\end{array}$ & 0.708 & 0.258 \\
\hline $\begin{array}{l}\text { Net opinion that accession of Turkey to the EU could risk favouring immigration to } \\
\text { more developed countries (QA34.6) }\end{array}$ & 0.589 & -0.214 \\
\hline $\begin{array}{l}\text { Net opinion that to join in about ten years, Turkey will have to respect systematically } \\
\text { human rights (QA34.7) }\end{array}$ & 0.266 & 0.907 \\
\hline $\begin{array}{l}\text { Net opinion that to join in about ten years, Turkey will have to significantly improve } \\
\text { the state of its economy (QA34.8) }\end{array}$ & 0.555 & 0.710 \\
\hline
\end{tabular}

Note: First component represents 50.572 percent and second component 22.088 percent of total variation of eight variables. No rotation is applied.

The two components represent together $70.66 \%$ of total variation specified in the correlation matrix. The first component represents $50.57 \%$ of variation with substantial loadings of seven variables. The second component represents $22.09 \%$ of variation with substantial loadings of two 
variables. Structure of loadings on the first component indicates that this dimension represents correlated statements that depict the 'thick' conception of EUrope. Some of the statements have been reflected in order to obtain positive loadings on the dimension. The highest loading (0.858) represents the opinion that Turkish accession would not strengthen regional security. Similar high loading (0.853) has the opinion that cultural differences between Turkey and the EU member states are too significant to allow for its accession. Also the statements that Turkey does not belong by its geography and history to EUrope loads high on this component $(0.811$ and 0.834 , respectively). The statements on rejuvenation of EU population and immigration have lower, but still significant loadings (0.708 and 0.586).

Fig. 1 Scores on the component 'thick' perception of EUrope and number of years of EU membership or candidate status in 2006.

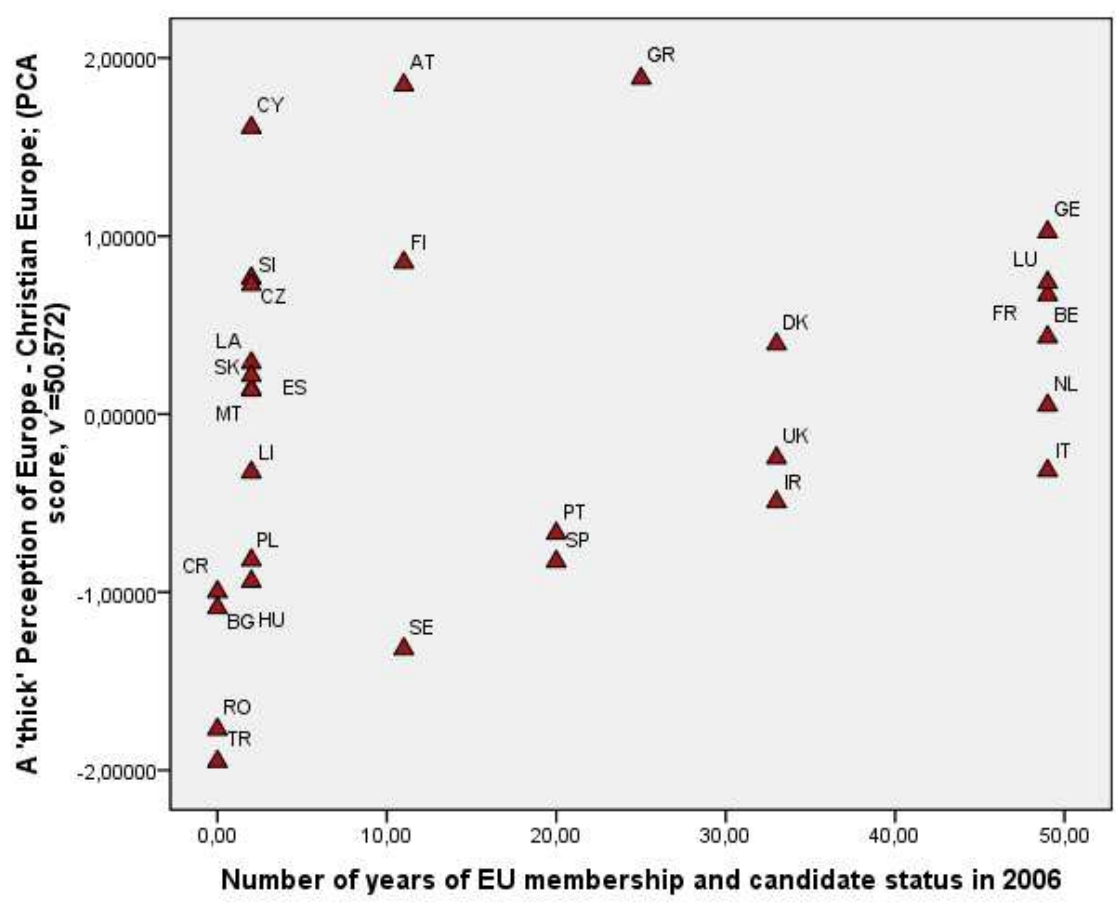


Figure 1 shows considerable differences in component scores representing the 'thick' perception of EUrope. It is little surprising that Greece (GR) and the Republic of Cyprus (CY) have the highest scores on this dimension. Also Austria (AT) takes on an extreme position on this dimension. It is also important to note the relatively high scores of the founding and influential member states of Germany (GE), France (FR), Belgium (BE) and Luxembourg (LU), while the Netherlands (NL) and Italy (IT) have component scores close to average. In the group of countries of the 1973 enlargement only Denmark (DK) shows a tendency to perceive EUrope in 'thick' terms. Spain (SP) and Portugal (PT) have scores on the negative side of the component and the same applies to Sweden (SE). It seems that these polities are therefore able to avoid strong orientation on the 'thick' perception of EUrope.

The scores on the 'thick' component of the ten member countries which joined EUrope in 2004 indicate considerable differentiation in the opinion on Turkish accession. Slovenia (SI) and the Czech Republic (CZ) show levels of 'thick' perception similar to the member states in the historical core of the EU as well as in Finland (FI), thus expressing considerable skepticism about Turkish accession. In contrast, Poland (PL) and Hungary (HU) clearly score on the negative side of the dimension. It seems that these polities give emphasis to the potential benefits of Turkey's bid for EU membership. Considering the two countries which would have joined EUrope in 2007, Romania (RO) and Bulgaria (BU), and the two candidate countries, Croatia and Turkey, it was somewhat expected that this latter country would have shown the lowest score on the 'thick' dimension. The score of Romania, however, is very close to the Turkish one and also Bulgaria and Croatia score on the negative side of this component. This suggests the tendency in these Balkan countries to assess Turkey's future full membership in positive terms. 
At the individual level, cross tabulations with 'cultural differences' - one of the components most clearly associated with a 'thick' dimension of EUrope - reveal that the highest percentage of respondents who favor the 'thick' view of EUrope are generally men (since female respondents are more undecided), aged between 55 and 64 years old, whose political ideas are on the center or centre-right of the political spectrum, who live in small or middle towns and who have been averagely educated (i.e., they left school when they were 17-18 years old). This distribution is somewhat expected, as it reflects the one observed above for respondents who are the most 'against' Turkey's EU membership.

The second component represents public opinion's views which can resonate with a 'thin' idea of EUrope (see Figure 2). The highest loading (0.907) on this dimension refers to the systematic respect of human rights, while the second substantial loading (0.710) refers to the significant improvement of Turkey's economy. It is interesting to note that this latter statement also loads significantly on the first component (0.555). This means that across the set of twentynine countries there is also important public opinion tendency to view Turkish accession also in instrumental terms (McLaren, 2007). 
Fig. 2 Scores on the component 'thin' perception of Europe and number of years of EU membership or candidate status in 2006.

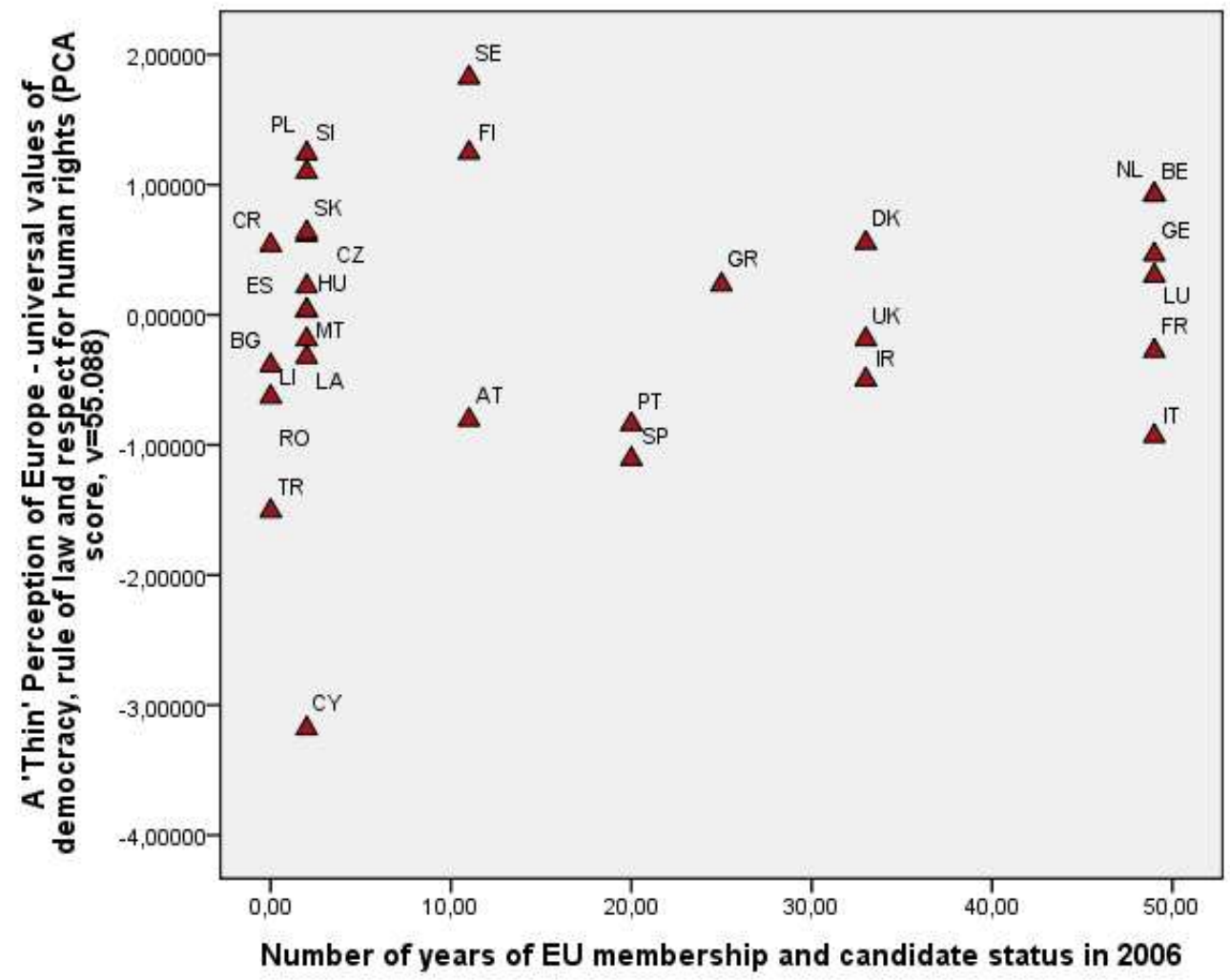

It is clear, from figure 2, that Sweden (SE) scores the highest value on this dimension, followed closely by Finland (FI), Poland (PL) and Slovenia (SI). The very negative score on this dimension of the Republic of Cyprus (CY) clearly indicates the skepticism towards Turkey being able to respect human rights. Greece (GR), somewhat surprisingly, does not follow the Republic of Cyprus on this view, as its score is close to the average of the set of the twenty-nine countries. Considering the candidate countries, it is interesting to note that Turkey scores on the negative side of the dimension. This position seemingly indicates the concerns about the EU disciplinizing impacts on Turkish accession. 
At the individual level, cross tabulations with both 'human rights' and 'economic improvement' - two of the components most clearly associated with a 'thin' dimension of EUrope - reveal a more complex socio-demographic profile of the respondent associated with this view of 'thin' EUrope. In fact, while the respondent is generally highly educated (holding a university degree) and lives in large towns, s/he might also have centre-right political views, as well as centre-left views (in the case of 'human rights') and might have an age spanning from 25 to 54 years old. As for gender, the respondent who privileges a 'thin' idea of EUrope is generally a man, but once again because women are more undecided. It is interesting to observe, then, that while a 'thick' idea of EUrope receive the highest support by the type of respondent (conservative, aged, moderately educated, living in small or middle towns) one might expect, this is not the case for the idea of 'thin' EUrope, which is associated with a respondent more blurred in terms of the socio-demographic characteristics.

\section{CONCLUSIONS}

Turkey's EU membership is clearly a contested issue when analyzed from the perspective of EUropean public opinions. Regional differences clearly exist in relation to this matter, as respondents of the NMS-12 tend to be less hostile than those of the EU-15 to the possibility that Turkey one day will join EUrope. The very notion of 'joining EUrope', however, should be problematized, as we have tried to show that in the present multi-speed EUrope there is not necessarily one way to be integrated. We have discussed three possible modalities through which Turkey can still integrate into EUrope, although we have also pointed out the limits associated with each of them. Our argument, however, is that when confronted with the possibility of Turkey's full membership, EUrope comes to be constructed in what we have termed 'thick' and 
‘thin' terms. A ‘thick' EUrope is one built around cultural, historical, and geographical bonds, which would oppose Turkey's EU membership. A 'thin' EUrope, instead, is one built around the normative-legalistic body of the acquis communautaire, as well as utilitarian economic principles. Within this perspective, Turkey could have the chance to join EUrope as long as it manages to implement and abide to this acquis communautaire. Given the fact that the multispeed character of the EUropean integration complicates and also erases cultural and historical divisions, this second perspective should be the most likely. Also according to Diez (2011), to let both sides negotiate within the established routines, rules and procedures of the enlargement processes would perhaps be the best way out of the EU-Turkey conundrum. In such a case, Turkey would be able to overcome the opposition of EUropean countries to its membership to the extent that it simply follows the fundamental norms of the EU. Yet, our analysis of survey data reveals a popular entrenched hostility to such a hypothesis. Public opinion's views are markedly against Turkey's future EU membership and it is difficult to see how national governments would be able to adopt a decision which would contrast so openly with the view of their electorates. It is interesting to observe that even in case Turkey complies with all the conditions set by the EU, still $78 \%$ of Austrian, $63 \%$ of German and $61 \%$ of French respondents would be against Turkey's EU membership (EB 69.2, 2008, QA45). This clearly points to the relevance of the 'thick' dimension, which cannot simply be dismissed by privileging a 'thin' logic. This 'thick' component elicits indeed an identity question, which is hard to overcome. Accordingly, the widespread image among the EUropean public is one of Turkey not 'being' EUropean, but potentially (if ever) 'becoming' EUropean (Diez, 2011). Within this context, a 'thin' logic would not suffice to bring Turkey into EUrope. It is for this reason that we believe that it is at the complex intersection of these two opposite views, 'thick' and 'thin', that Turkey's bid for EU membership should be located and eventually decided. 


\section{REFERENCES}

Akçall, Emel, Chypre: Un enjeu géopolitique actuel. Paris: L’Harmattan, 2009

Akçalı, Emel, "EU, Political Islam and Polarization of Turkish Society”, in M. Pace (ed.) Europe, the USA and Political Islam: Strategies for engagement. Basingstoke: Palgrave Macmillan, pp: 40-57, 2011.

Akçalı, Emel and Perinçek, Mehmet, "Kemalist Eurasianism: An emerging Geopolitical discourse in Turkey", Geopolitics, 14 (3): 550-569, 2009.

Antonsich, Marco, "EUropean attachment and meanings of EUrope. A qualitative study in the EU-15”, Political Geography, 27 (6): 691-710, 2008.

Antonsich, Marco Bringing the demos back in: People's views on European identity. Paper delivered at the conference Identity, norms, community, discourse: cultural approaches to European integration, University of Bristol, Department of Politics, May, 12 2010.

Arikan, Harun, Turkey and the EU: An awkward candidate for EU membership? Aldershot: Ashgate, 2003.

Aybet, Gülnur, "Turkey and the EU, After the First Year of Negotiations: Reconciling Internal and External Policy Challenges”, Security Dialogue 37, pp: 529-49, 2006.

Barke, H.J. and Le Gloannec, A.M., "The Strategic Implications of Turkey's Integration in the European Union", in Brimmer, E., and Frölilich, S., (eds.) The Strategic Implications of European Union Enlargement. Washington D.C.: Center for Transatlantic Relations, The John Hopkins University, 127-150, 2005.

Baykal, Sanem, Unity or Diversity? The Challenge of Diversity for the European Political Identity, Legitimacy and Democratic Governance: Turkey's EU Membership as the Ultimate 
Test Case. New York: Jean Monet Working Paper 09/05, New York University School of Law, 2005.

Bilgin, Pinar and Bilgiç, Ali, Turkey and Eurasia during the AKP era: Civilisational Geopolitics redux. Eurasian Geography and Economics, this issue, 2011.

Çarkoğlu, Ali, "Who Wants Full Membership? Characteristics of Turkish Public Support for EU Membership", Turkish Studies, 4, 1: 171-194. 2003.

Cohen, Saul B., “The Geopolitics of Turkey’s Accession to the European Union”, Eurasian Geography and Economics, 45, 8:575-582. 2004.

Dahlman, Carl, “Turkey's Accession to the European Union: The Geopolitics of Enlargement”, Eurasian Geography and Economics, 45, 8:553-574, 2004.

Davutoğlu, Ahmet, “Turkey’s Foreign Policy Vision: An assessment of 2007”, Insight Turkey 10, pp: 77-79, 2008.

Diez, Thomas, "Promises, Obligations, Impatience and Delay: Reflections on the Ethical Aspects of Turkey-EU relations" in A. E. Čakır, (ed.) Fifty Years of EU-Turkey Relations. London: Routledge, pp. 158-175, 2011.

Dinan, Desmond, Ever Closer Union: An Introduction to European Integration. Basingstoke: Palgrave Macmillan, 2005.

Dostál, Petr, Risks of a Stalemate in the European Union: a Macro-Geography of Public Opinion. Prague: Geographica Series, volume 5, Czech Geographic Society, 2010a.

Dostál, Petr, Multi-Speed European Union: Differentiated Integration and Spatial Development in Public Opinion. Prague: Geographica Series, volume 6, Czech Geographic Society, $2010 \mathrm{~b}$.

Dostál, Petr, "Environment and regional cohesion in the enlarged European Union - differences in public opinion”, in Anděl, J., Bičík, I., Dostál, P., Lipský, Z. and Shahneshin, S.G. (eds.) 
Landscape Modelling: Geographical Space, Transformation and Future Scenarios. New York: Springer Science, 59-77. 2010c.

Elliasen, Kjell A. and Sitter, Nick The Quit European: Norway's Quasi-Membership of the European Union. Report 1. Sandvika: Centre for European and Asian Studies at Norwegian School of Management, 2004.

Gabel, Matthew, Interests and Integration: Market Liberalization, Public Opinion and European Union. Ann Arbor: University of Michigan Press, 1998.

Habermas, Jürgen, The Postnational Constellation. Cambridge MA: MIT Press, 2001.

Helvaçioğlu, Banu, "The Paradoxical Logic of Europe in Turkey: When Does Europe End?" European Legacy, 4, 3:18-34, 1999.

Hix, Simon, The Political System of the European Union. Basingstoke: Palgrave Macmillan, 2005.

Kentmen, Cigdem, 2008. "Determinants of Support for EU Membership in Turkey:

Islamic Attachments, Utilitarian Considerations and National Identity", European Union Politics, 9,4: 487-510.

Jolly, Seth and Oktay, Sibel, Explaining Turkish Party and Public Support for the EU. Unpublished paper presented at the Biennial Meeting of the European Union Studies Association, Boston, 3-5 March 2011 (available at http://www.euce.org/eusa/2011/papers/4h_jolly.pdf).

Kinacioğlu, Müge. and Oktay, Emel, “The Domestic Dynamics of Turkey’s Cyprus Policy: Implications of Turley's Accession to the European Union,” Turkish Studies, 7, 2: 261-273, 2006.

Mango, Andrew, Atatürk. London: John Murray Publishers, 2001. 
McCornick, John P., Weber, Habermas, and Transformations of the European State:

Constitutional, Social, and Supranational Democracy. Cambridge: Cambridge University Press, 2009.

McLaren, Lauren M., "Explaining opposition to Turkish membership of the EU", European Union Politics, 8, 2:251-278, 2007.

Molle, Willem, European Cohesion Policy. London: Routledge, 2007.

Morgan, Glyn, The Idea of a European Superstate: Public Justification and European Integration. Princeton: Princeton University Press, 2005.

Müftüler-Baç, Meltem, “Turkey’s Role in the EU's Security and Foreign Policies”, Security Dialogue, 31, 4: 399-502, 2000.

Murphy, Alexander B., “Turkey's Place in the Europe of the 21st Century”, Eurasian Geography and Economics, 45, 8:583-587, 2004.

Rosamond, Ben, Theories of European Integration. Basingstoke: Palgrave Macmillan, 2000.

Rummel, Rudolph J., Applied Factor Analysis. Evaston: Northwestern University Press. 1970.

Schimmelfenning, Frank, "Entrapped again: the way to EU membership negotiations with Turkey”, International Politics, 46, 4: 413-31, 2009.

Taggart, Paul and Szczerbiak, Aleks, "Contemporary Euroscepticism in the Systems of the European Union Candidate States of Central and Eastern Europe", European Journal of Political Research, 43,1: 1-27, 2004.

Tocci, Nathalie, "Europeanization in Turkey: Trigger or anchor for reform?" South European Society and Politics, 10 (1), 73-83, 2005.

WWR (The Netherlands Scientific Council for Government Policy), The European Union, Turkey and Islam. Amsterdam: Amsterdam University Press. 2004. 
Yanık, Lerna, “Constructing Turkish 'Exceptionalism': Discourses of Liminality and Hybridity in Turkish Foreign Policy”, Political Geography, 30, 2: 80-89, 2011.

Yavuz, Hakan, Secularism and Muslim Democracy in Turkey. Cambridge: Cambridge University Press, 2009.

Yllmaz, Hakan "Turkish Identity on the Road to the EU: Basic Elements of French and German Oppositional Discourses", Journal of Southern Europe and the Balkans, 9, 3: 293-305, 2007. Zeynalov, Mahir, “Turkey Gains New Vision in Foreign Affairs Under Davutoğlu”, Sunday’s Zaman, 13 September 2009.

Zeynalov Mahir, “One year with Davutoglu strengthens Turkey's foreign policy”, Sunday's Zaman, 2 May 2010.

Zielonka, Jan, Europe as Empire. The Nature of the Enlarged European Union. Oxford: Oxford University Press. 2006.

\footnotetext{
${ }^{1}$ The spelling 'EUrope' in this article aims to convey the idea that Europe, as a complex geographical and historical idea has been subsumed within the hegemonic b-ordering logic of the European Union (Antonsich, 2008).

${ }^{2}$ At the EU summit of Copenhagen, in June 1993, the political representations of the twelve member states agreed that any accession could only take place after an associated country was able to assume obligations of membership and satisfy the required economic and political conditions (democracy, civil rights, respect for minorities, and economic criteria of market economy).

${ }^{3}$ Some historical sources also mention another coup in 1997. On February 28th, 1997, the Turkish military exercised pressure on the then prime minister Necmettin Erbakan, leader of the Islamist Refah Partisi (Welfare Party), which finally put an end to his coalition government. Since the government was forced out without the dissolution of the Parliament, this event is also referred to by Turkish journalistic sources as a 'postmodern coup'.
} 
${ }^{4}$ In their analysis of EUropean attitudes of Turkish political parties, Jolly and Oktay (2011) adopts a different categorization. Following Taggart and Szczerbiak (2004), they indeed talk of 'hard Euroskeptics' (those who reject the entire project of EUropean integration) and 'soft EUroskeptics' (those who express a contingent or qualified opposition to the EU) and affirm that all political parties in Turkey are 'soft Euroskeptics', although to various degree.

${ }^{5}$ For purpose of synthesis, Bulgaria and Romania, which joined EUrope in January 2007, are shown to belong to the NMS-12 group also before 2007. This will be done also for other surveys in this article.

${ }^{6}$ Data from Eurobarometer (EB) surveys used in this article do not allow analyzing regional differences among Turkish respondents, but one can refer to major outcomes of surveys carried out in Turkey (Çarcoğlu, 2003). In this regard, some socio-spatial patterns clearly emerge. First, strong support for Turkish membership is more likely to exist in the metropolitan provinces of Turkey's biggest cities, such as Istanbul. Second, there exists a West-East gradient indicating across Turkish provinces increasing opposition in the Eastern parts of the country. Third, and somewhat in contradiction with this second point, provinces where the Kurdish minority is present, also tend to support Turkey's EU membership. Yavuz $(2009,14)$ adds to these regional differences also the importance of the emerging Anatolian bourgeoisie with its EU ambitions.

${ }^{7}$ Secondary data related to these surveys are available on the website of the International Republican Institute (http://www.iri.org/countries-and-programs/europe/turkey), whereas primary data can be requested to the Infakto Research Workshop (http://www.infakto.com.tr/).

${ }^{8}$ When compared with Eurobarometer data regarding the same question on Turkey's EU membership, there is a rather relevant difference in value (8\%) for the survey year 2006. Both Eurobarometer and Infakto adopt similar sampling techniques, using as survey units the NUTS 2 regions (the Nomenclature of Territorial Units for Statistics adopted by Eurostat), even though the sampling population of Eurobaromer in Turkey is 1,000 whereas the one of Infakto is 1,500 (2,000 for the surveys administered in May 2010 and later). Estimated sampling error under the simple random sampling assumption is \pm 2.18 for the Infakto surveys and \pm 1.9 for Eurobarometer surveys, both at the 95percent level of confidence. Both surveys are administered in-person, but while the Infakto survey population is 18 years old and above, Eurobatometer's is 15 years old and above.

${ }^{9}$ The utilitarian factor as a key drive in explaining EUropean support among the Turkish public is confirmed by statistical analysis - see Kentmen (2008) and Jolly and Oktay (2011). 
${ }^{10}$ Ironically, today Turkey's economic performance overcome by far EUrope's, as for instance the GDP growth predicted in 2011 by the OECD for the Turkey is $5.7 \%$ against $1.7 \%$ of the Euro area (source: OECD economic outlook n. 88 - www.oecd.org/oecdeconomicoutlook - last accessed 15 March 2011) 